\title{
CHARACTERIZATION OF STAPHYLOCOCCUS AUREUS ISOLATED FROM TILAPIA AND UTENSILS USED IN THE SALE OF TILAPIA IN THE STREET MARKETS OF A SEMI-ARID BRAZILIAN MUNICIPALITY
}

\author{
Tayla M. A. Correia, Anay P. D. Oliveira, Isabela F. Miyasato, Tamires M. B. Santos, \\ Francesca S. Dias ${ }^{\bowtie}$ \\ Federal University of Sãn Francisco Valley (UNIVASF) \\ Rod. BR 407, Km 12 - Lote 543 - Projeto de Irrigação Senador Nilo Coelho, s/nº - C1, 56.300-990, Petrolina, Pernambuco, Brazil
}

\begin{abstract}
Background. The production and sale of tilapia (Oreochromis niloticus) is fundamentally important to the semi-arid region of northeastern Brazil. In this region, one of the main forms of sale occurs in street markets (fairs). A high incidence of methicillin-resistant Staphylococcus aureus (MRSA) strains was previously detected in different food-related environments in Brazil. However, limited data is available about the presence of MRSA in street markets commercializing tilapias. In this study, we identified Staphylococcus aureus from tilapia and utensils used in the sale of tilapia in the street markets of a semi-arid Brazilian municipality and characterized the virulence potential of the isolates by analyzing their $\beta$-lactam resistance, intercellular adhesion and enterotoxin genes.

Materials and methods. The study used samples from the 5 main markets in the city. Phenotypic tests to determine antimicrobial resistance, exopolysaccharide (EPS) production, the potential for biofilm formation and cell surface hydrophobicity were conducted on $S$. aureus isolates. The presence of antimicrobial resistance genes (mecA and blaZ), potential biofilm production genes (ica $\mathrm{A}$ and icaD) and enterotoxin (se) genes was investigated.

Results. Coagulase-positive staphylococci (CoPS) were detected in samples from all markets in discordance with the legal limits in force. Twelve isolates were confirmed to be $S$. aureus. Ten isolates demonstrated multidrug resistance (MDR). All isolates were able to produce EPS and form biofilms. Eight isolates exhibited strong hydrophobicity and six a high potential for biofilm formation. Twelve isolates were positive for mecA, blaZ, icaD and sed.

Conclusion. Tilapia marketed in unsuitable conditions may be a vehicle for staphylococcal food poisoning and for the dissemination of MRSA to consumers. Additionally, the ability of the isolates to produce biofilms is an alert to the presence and persistence of these virulent microorganisms on utensils used for the commercial distribution of tilapia.
\end{abstract}

Keywords: tilapia, MRSA, antimicrobial resistance, biofilm, enterotoxins

\footnotetext{
francescadiasnobre@gmail.com, francesca.nobre@univasf.edu.br, https://orcid.org/0000-0003-0174-4397, phone +558721014839
} 


\section{INTRODUCTION}

The public fishing terminal of Sobradinho, Bahia, which is in the San Francisco Valley within the semiarid region of Brazil, pioneered the commercial fishing of tilapia using floating net cages and has the support of "Bahia Pesca" (Bahia Fishing) and the "Companhia de Desenvolvimento dos Vales do São Francisco e Parnaíba" (San Francisco and Parnaíba Valley Development Company) (CODEVASF). The cultivation and sale of tilapia (Oreochromis niloticus) is fundamental to the region and guarantees income for many families in this semi-arid area (Bahia Pesca, 2014). One form of tilapia sale occurs in street markets (fairs), such as those in Petrolina in the state of Pernambuco, Brazil; a city next to the fishing terminal of Sobradinho (50 km; Fig. 1).

Fish products are highly perishable, so extreme care must be taken during their handling and sale Mishandling of fish can lead to cross-contamination from various sources. One of the main sources of crosscontamination is utensils, such as cutting tables and knives. Cross-contamination with Staphylococcus aureus is a major issue (Gatti Junior et al., 2014). Thus, whole and filleted tilapia may be a potential risk to consumer health. In 2015, a total of 434 outbreaks caused by staphylococcal toxins were reported by 16 member states of the European Union (EU) and fish and fish products were associated with 18 outbreaks, representing $4.15 \%$ of the total staphylococcal food
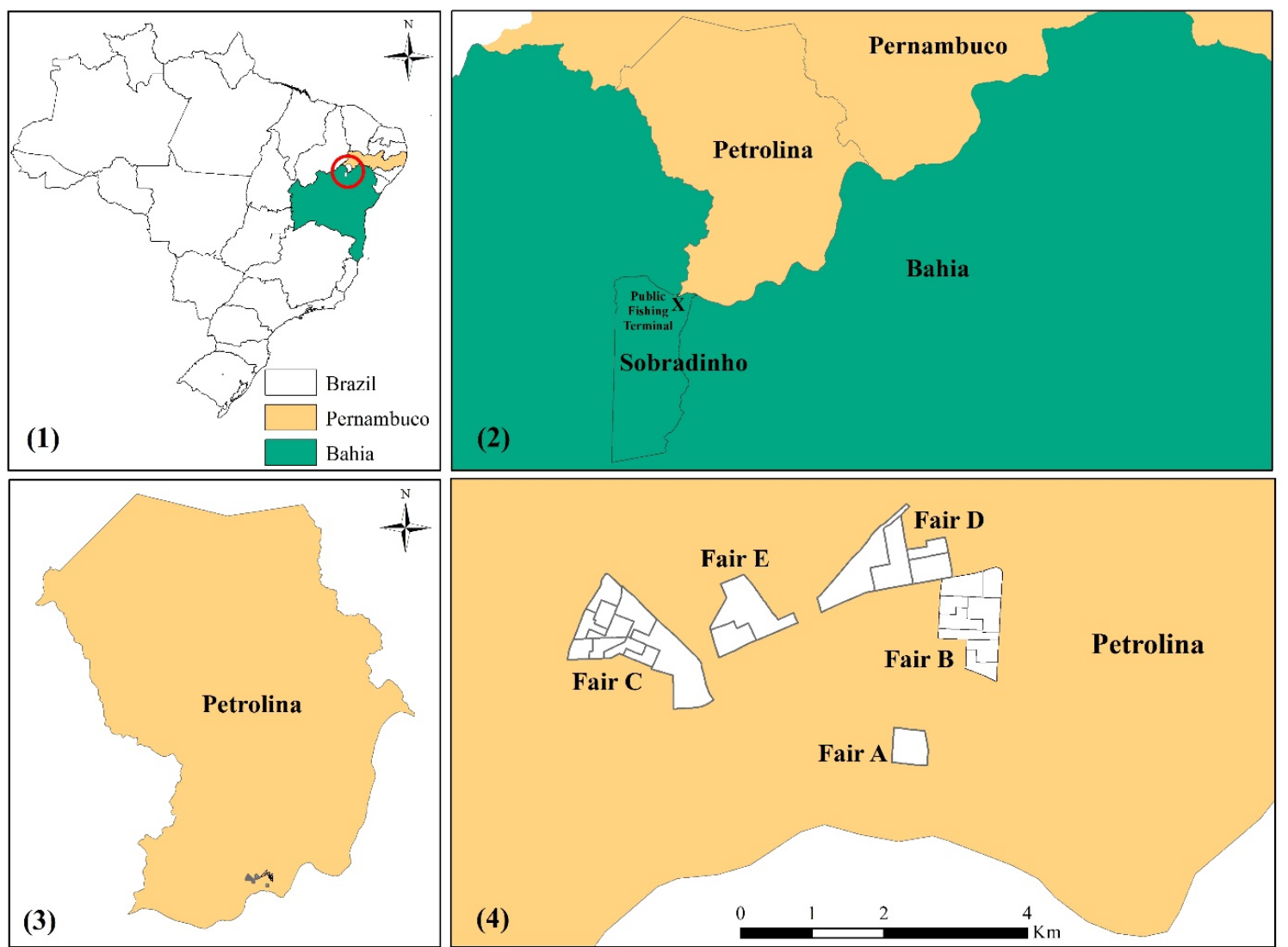

Fig. 1. Location: 1 - map of Brazil showing the locations of the states of Bahia and Pernambuco, with a circle denoting the cities of Sobradinho and Petrolina; 2 - map showing Sobradinho and Petrolina, cities of the states of Bahia and Pernambuco, respectively; 3 - map of Petrolina, highlighting the city districts with free fairs; 4 - the 5 city districts of the city of Petrolina where the fairs are located (IBGE, Census Sector, 2010) 
poisoning outbreaks reported in the EU (EFSA, 2016). In the United States of America (USA), tilapia was the implicated food vehicle in 2 outbreaks caused by staphylococcal toxins in the states of Florida (in 2014) and Pennsylvania (in 2006), which caused 2 and 17 cases of illness, respectively (CDC-NORS, 2019).

In addition to producing enterotoxins, $S$. aureus has the inherent ability to form biofilms on biotic and abiotic surfaces (Doulgeraki et al., 2017). Among the pathways to form the biofilm matrix, the ica operon can regulate the formation of biofilms by $S$. aureus through the production of polysaccharide intercellular adhesin (PIA), and the genes $i c a \mathrm{~A}$ and $i c a \mathrm{D}$ play a role in this process. Biofilms are aggregates of microbial cells that accumulate in multiple layers within an organic polymer matrix. This matrix, which is composed mainly of exopolysaccharide (EPS) and proteins that provide cohesion and sustainability, confers resistance to various stress conditions, sanitizers used in the food industry, and the host's immune system. Thus, biofilms contribute to $S$. aureus dissemination and infection (Joyce et al., 2003; Vázquez-Sánchez and Rodríguez-López, 2018).

The fact that biofilms disseminate antimicrobial resistance across cells is noteworthy; the extracellular DNA present in the matrix can contribute to horizontal gene transfer (Vázquez-Sánchez and Rodríguez-López, 2018). With regards to antimicrobial resistance, methicillin-resistant Staphylococcus aureus (MRSA) is one of the most important antibiotic-resistant pathogens in humans and various animal species. MRSA presents cross-resistance to almost all $\beta$-lactam antibiotics, which constitute an antibiotic class of great clinical importance. MRSA is the main cause of nosocomial infections in Latin America. In fact, MRSA is an emergent pathogen in Brazil (Carvalho et al., 2019; Ossa et al., 2018). Thus, the aim of this study was to isolate and identify $S$. aureus in tilapia and utensils used in street markets located in Petrolina, and determine their virulence potential by investigating their resistance to $\beta$-lactam, intercellular adhesion and enterotoxin genes.

\section{MATERIALS AND METHODS}

\section{Sample collection}

A total of 100 freshly eviscerated tilapia (20 from each street market), 25 table swabs (5 from each street market) and 25 knife swabs (5 from each street market) were collected from the five main street markets in Petrolina (Fig. 1). The samples were collected during the period from August to December 2016 with the support of the Municipal Sanitary Surveillance Agency of Petrolina, Pernambuco state, Brazil. This agency can randomly collect 4 products per fair for free and can obtain 1 sample from utensils used for sale monthly. Thus, based on the collection permission of the agency, the sample size (for tilapia and utensils) was determined during the study period.

Each freshly eviscerated tilapia was stored in an individual sterile plastic bag (Gatti Junior et al., 2014) and refrigerated. For analysis of table and knife surfaces (25 of each), the areas were limited to $10 \mathrm{~cm} \times$ $10 \mathrm{~cm}$ with the aid of a sterile square mold. Areas (100 $\mathrm{cm}^{2}$ surface) were swabbed in both vertical and horizontal positions. At each position, the surface within the mold was rubbed from top to bottom and left to right, as described by Martinon et al. (2012), with a swab that was previously moistened in sterile trypticase soy broth (HiMedia, Mumbai, India) supplemented with $7.5 \% \mathrm{NaCl}$ (TSBS) (Xing et al., 2016).

\section{Isolation of coagulase-positive staphylococci (CoPS) and identification of S. aureus}

Isolation of CoPS and biochemical confirmation of CoPS and $S$. aureus were conducted using the methodology described by Brasil (2003). To obtain $25 \mathrm{~g}$ of samples, the procedures of Gatti Junior et al. (2014) were used. Briefly, $25 \mathrm{~g}$ of muscle was removed from the antero-dorsal region of a freshly eviscerated tilapia (gloves were used, and the knives were sterilized before being used to manipulate each fish sample) and homogenized in $225 \mathrm{~mL}$ of peptone water $(0.1 \%)$ (HiMedia). For samples from table and knife surfaces, after sampling the area, each swab was immersed in 30 $\mathrm{mL}$ of TSBS in a $50 \mathrm{~mL}$ sterile tube and incubated at $35^{\circ} \mathrm{C}$ for $24 \mathrm{~h}$ (Xing et al., 2016). Serial dilutions were made $\left(10^{-1}\right.$ to $\left.10^{-8}\right)$ in sterile peptone water (HiMedia). Baird Parker agar (Sigma-Aldrich, St. Louis, MO, USA) was used. To each $950 \mathrm{~mL}$ of base medium, 50 $\mathrm{mL}$ of sterile egg yolk emulsion (50\%, HiMedia) and $3 \mathrm{~mL}$ of potassium tellurite solution (Sigma-Aldrich, $3.5 \%$ ) were added. Aliquots of $0.1 \mathrm{~mL}$ of each sample were spread onto Baird-Parker agar in duplicate and incubated at $37^{\circ} \mathrm{C}$ for $24-48 \mathrm{~h}$. For CoPS detection, 
20-200 typical colonies on plates (colonies with black centers surrounded by clear halos) were counted. The microbiological counts were expressed as the logarithm of the number of colony-forming units per unit weight or per unit area $\left(\mathrm{CFU} / \mathrm{g}\right.$ or $\left.\mathrm{CFU} / \mathrm{cm}^{2}\right)$. According to the methods of Xing et al. (2016), two colonies per sample were selected from each plate and subjected to further analysis. For phenotypic confirmation from the typical colonies, Gram staining (Gram Staining Kit, Laborclin, Pinhais, PR, Brazil), enzyme activity assays (for coagulase and catalase; Laborclin), and glucose and mannitol (Synth, Diadema, SP, Brazil) fermentation assays were performed. For phenotypic confirmation of $S$. aureus, thermonuclease enzyme activity was verified.

The DNA of isolates that were biochemically identified as $S$. aureus was extracted using a PureLink Genomic DNA Mini Kit (Invitrogen, Carlsbad, CA, USA) according to the manufacturer's instructions. PCR was used to detect the expression of the thermonuclease gene (nuc) according to the protocol described by Xing et al. (2016). The 16S rRNA gene was amplified as described by Lange et al. (2011). All PCRs were carried out using an Applied Biosystems 2720 thermocycler (Applied Biosystems, Carlsbad, CA, USA). The primers used, PCR conditions, product sizes (bp) and protocols used for each gene are given in Table 1. The PCR products were separated on $0.8 \%$ agarose gels and visualized by staining with Safer ${ }^{\circledR}$ dye (Kasvi, São José dos Pinhais, PR, Brazil) using an LED transilluminator (470 nm) (Kasvi). Sequencing of the generated amplicons was performed by Helixxa (Paulínia, SP, Brazil), and the sequences were compared for similarity with sequences from the GenBank public database.

\section{Detection of mecA and blaz genes and antimicrobial resistance testing}

The genes encoding penicillin resistance (blaZ) and methicillin resistance (mecA) were detected according to the methodology of Sawant et al. (2009), with modifications. PCR was carried out using a premixed, ready-to-use GoTaq ${ }^{\circledR}$ Green Master Mix 2 X solution (Promega, Madison, WI, USA) in a total volume of $25 \mu \mathrm{L}$, which included $12.5 \mu \mathrm{L}$ of Master Mix, $8.5 \mu \mathrm{L}$ of nuclease-free water, $2 \mu \mathrm{L}$ of DNA $(50 \mathrm{ng} / \mu \mathrm{L})$ and $1 \mu \mathrm{L}$ of each primer $(10 \mathrm{pmol} / \mu \mathrm{L}$; Table 1$)$.
The primers, PCR conditions, fragment sizes (bp) and protocols used for each gene are described in Table 1. S. aureus American Type Culture Collection (ATCC) strain 29213 and S. aureus ATCC 33591 provided by the Fundação Oswaldo Cruz (FIOCRUZ) (Rio de Janeiro, RJ, Brazil) were used as negative and positive controls, respectively. The PCR products were visualized as previously mentioned.

The antibiotic resistance of the $S$. aureus isolates was tested using the disc diffusion method of the Clinical and Laboratory Standards Institute (CLSI) (2018). Twelve antimicrobials (Interlab, São Paulo, SP, Brazil) were used, including clindamycin $(2 \mu \mathrm{g} / \mathrm{disc})$, erythromycin $(15 \mu \mathrm{g} / \mathrm{disc})$, penicillin $(10 \mu \mathrm{g} / \mathrm{disc})$, oxacillin ( $1 \mu \mathrm{g} /$ disc $)$, cefoxitin $(30 \mu \mathrm{g} /$ disc $)$, rifampicin (5 $\mu \mathrm{g} / \mathrm{disc})$, chloramphenicol (30 $\mu \mathrm{g} / \mathrm{disc})$, vancomycin $(30 \mu \mathrm{g} / \mathrm{disc})$, gentamicin $(10 \mu \mathrm{g} / \mathrm{disc})$, ciprofloxacin $(5 \mu \mathrm{g} / \mathrm{disc})$, sulfamethoxazole + trimethoprim (25 $\mu \mathrm{g} / \mathrm{disc})$, and tetracycline (30 $\mu \mathrm{g} / \mathrm{disc})$. The diameters of the inhibition zones were then measured. S. aureus ATCC 25923 was used as a positive control. The test was performed in triplicate.

\section{Quantification of exopolysaccharide (EPS) production}

Exopolysaccharide - EPS production was quantified as described by Van Geel-Schuttens et al. (1998), with minor modifications. After each $S$. aureus isolate was cultured in a tube containing $20 \mathrm{~mL}$ of brain heart infusion (BHI, HiMedia) broth for 3 days at $37^{\circ} \mathrm{C}$, the cells were collected by centrifugation $(6000 \times \mathrm{g})$ for $20 \mathrm{~min} .99 .8 \%$ ethanol (Vetec, Duque de Caxias, RJ, Brazil) was added in a ratio of 2 parts to 1 part supernatant to precipitate EPS. Vacuum filtration was performed using paper filters (Unifil ${ }^{\circledR}$, Alvorada, RS, Brazil) that had previously been labeled and weighed. After filtration, the filters were placed in trays and incubated at $60^{\circ} \mathrm{C}$ for $3 \mathrm{~h}$, and the weight of each filter was again measured to quantify the EPS produced.

\section{Cell surface hydrophobicity assay}

Cell surface hydrophobicity was evaluated according to the methods of Rodrigues et al. (2009). Each isolate was inoculated into two tubes containing BHI. One tube was incubated for $4 \mathrm{~h}$ at $37^{\circ} \mathrm{C}$, while the other was incubated for $24 \mathrm{~h}$ at $37^{\circ} \mathrm{C}$. For both time points, 
Correia, T. M. A., Oliveira, A. P. D., Miyasato, I. F., Santos, T. M. B., Dias, F. S. (2019). Characterization of Staphylococcus aureus isolated from tilapia and utensils used in the sale of tilapia in the street markets of a semi-arid Brazilian municipality. Acta Sci. Pol. Technol. Aliment., 18(4), 413-425. http://dx.doi.org/10.17306/J.AFS.2019.0727

Table 1. Oligonucleotide sequences and PCR protocols for identification of $S$. aureus isolates and detection of $\beta$-lactam resistance, intercellular adhesion and enterotoxin genes

\begin{tabular}{|c|c|c|c|c|}
\hline Gene & $\begin{array}{c}\text { Sequence, } 5{ }^{\prime}-3^{\prime} \\
\text { (F: Forward / R: Reverse) }\end{array}$ & PCR protocol & $\begin{array}{l}\text { Product } \\
\text { size }(b p)\end{array}$ & Reference \\
\hline$n u c$ & $\begin{array}{l}\text { F: GCGATTGATGGTGATACGGTT } \\
\text { R: AGCCAAGCCTTGACGAACTAAAGC }\end{array}$ & $\begin{array}{l}\text { Initial denaturation for } 5 \mathrm{~min} \text { at } 94^{\circ} \mathrm{C} \text {; } \\
1 \mathrm{~min} \text { at } 94^{\circ} \mathrm{C} \text {, annealing for } 0.5 \mathrm{~min} \\
\text { at } 52.7^{\circ} \mathrm{C} \text { and extension for } 1.5 \mathrm{~min} \\
\text { at } 72^{\circ} \mathrm{C} \text { for } 37 \text { cycles; final extension } \\
\text { for } 3.5 \mathrm{~min} \text { at } 72^{\circ} \mathrm{C} \text {. }\end{array}$ & 279 & $\begin{array}{l}\text { Xing } \\
\text { et al. } \\
(2016)\end{array}$ \\
\hline 16S-rRNA & $\begin{array}{l}\text { F: AGAGTTTGATCCTGGCTCAG } \\
\text { R: GTATTACCGCGGCTGCTG }\end{array}$ & $\begin{array}{l}\text { Initial denaturation for } 5 \mathrm{~min} \text { at } 95^{\circ} \mathrm{C} \text {; } \\
0.5 \mathrm{~min} \text { at } 95^{\circ} \mathrm{C} \text {, annealing for } 0.5 \mathrm{~min} \\
\text { at } 55^{\circ} \mathrm{C} \text { and extension for } 2 \mathrm{~min} \text { at } 74^{\circ} \mathrm{C} \\
\text { for } 35 \text { cycles; final extension for } 5 \mathrm{~min} \\
\text { at } 74^{\circ} \mathrm{C} \text {. }\end{array}$ & 536 & $\begin{array}{l}\text { Lange } \\
\text { et al. } \\
(2011)\end{array}$ \\
\hline mecA & $\begin{array}{l}\text { F: AAAATCGATGGTAAAGGTTGGC } \\
\text { R: AGTTCTGCAGTACCGGATTTGC }\end{array}$ & $\begin{array}{l}\text { Initial denaturation for } 4 \mathrm{~min} \text { at } 95^{\circ} \mathrm{C} \text {; } \\
0.5 \mathrm{~min} \text { at } 95^{\circ} \mathrm{C} \text {, annealing for } 0.5 \mathrm{~min} \\
\text { at } 52^{\circ} \mathrm{C} \text { and extension for } 0.5 \mathrm{~min} \text { at } 72^{\circ} \mathrm{C} \\
\text { for } 30 \text { cycles; final extension for } 5 \mathrm{~min} \\
\text { at } 72^{\circ} \mathrm{C} \text {. }\end{array}$ & 533 & $\begin{array}{l}\text { Sawant } \\
\text { et al. } \\
(2009)\end{array}$ \\
\hline blaZ & $\begin{array}{l}\text { F: AAGAGATTTGCCTATGCTTC } \\
\text { R: GCTTGACCACTTTTATCAGC }\end{array}$ & $\begin{array}{l}\text { Initial denaturation for } 4 \mathrm{~min} \text { at } 95^{\circ} \mathrm{C} \text {; } \\
0.5 \mathrm{~min} \text { at } 95^{\circ} \mathrm{C} \text {, annealing for } 0.5 \mathrm{~min} \\
\text { at } 50^{\circ} \mathrm{C} \text { and extension for } 0.5 \mathrm{~min} \text { at } 72^{\circ} \mathrm{C} \\
\text { for } 30 \text { cycles; final extension for } 5 \mathrm{~min} \\
\text { at } 72^{\circ} \mathrm{C} \text {. }\end{array}$ & 517 & $\begin{array}{l}\text { Sawant } \\
\text { et al. } \\
(2009)\end{array}$ \\
\hline sea & $\begin{array}{l}\text { F: ACGATCAATTTTTACAGC } \\
\text { R: TGCATGTTTTCAGAGTTAATC }\end{array}$ & \multirow{4}{*}{$\begin{array}{l}\text { Initial denaturation for } 5 \text { min at } 95^{\circ} \mathrm{C} \text {; } \\
1 \mathrm{~min} \text { at } 95^{\circ} \mathrm{C} \text {, annealing for } 1 \mathrm{~min} \\
\text { at } 44.5^{\circ} \mathrm{C} \text { and extension for } 1 \mathrm{~min} \\
\text { at } 72^{\circ} \mathrm{C} \text { for } 37 \text { cycles; final extension } \\
\text { for } 10 \text { min at } 72^{\circ} \mathrm{C} \text {. }\end{array}$} & 544 & \multirow{4}{*}{$\begin{array}{l}\text { Kroning } \\
\text { et al. } \\
(2016)\end{array}$} \\
\hline seb & $\begin{array}{l}\text { F:ATTCTATTAAGGACACTAAGTTAGGGGA } \\
\text { R: ATCCCGTTTCATAAGGCGAGT }\end{array}$ & & 404 & \\
\hline sed & $\begin{array}{l}\text { F: CAAATATATTGATATAATGA } \\
\text { R: AGTAAAAAAGAGTAATGCAA }\end{array}$ & & 330 & \\
\hline see & $\begin{array}{l}\text { F: CAAAGAAATGCTTTAAGCAATCTTAGGC } \\
\text { R: CACCTTACCGCCAAAGCTG }\end{array}$ & & 482 & \\
\hline $\mathrm{sec}$ & $\begin{array}{l}\text { F: GACATAAAAGCTAGGAATTT } \\
\text { R: AAATCGGATTAACATTATCCA }\end{array}$ & $\begin{array}{l}\text { Initial denaturation for } 5 \mathrm{~min} \text { at } 95^{\circ} \mathrm{C} \text {; } \\
45 \mathrm{~s} \text { at } 95^{\circ} \mathrm{C} \text {, annealing for } 45 \mathrm{~s} \text { at } 46.2^{\circ} \mathrm{C} \\
\text { and extension for } 45 \mathrm{~s} \text { at } 72^{\circ} \mathrm{C} \text { for } 35 \\
\text { cycles; final extension for } 10 \mathrm{~min} \text { at } 72^{\circ} \mathrm{C} \text {. }\end{array}$ & 257 & $\begin{array}{l}\text { Kroning } \\
\text { et al. } \\
(2016)\end{array}$ \\
\hline$i c a \mathrm{~A}$ & $\begin{array}{l}\text { F: CCTAACTAACGAAAGGTAG } \\
\text { R: AAGATATAGCGATAAGTGC }\end{array}$ & \multirow{2}{*}{$\begin{array}{l}\text { Initial denaturation for } 5 \mathrm{~min} \text { at } 92^{\circ} \mathrm{C} \text {; } \\
45 \mathrm{~s} \text { at } 92^{\circ} \mathrm{C} \text {, annealing for } 45 \mathrm{~s} \text { at } 49^{\circ} \mathrm{C} \\
\text { and extension for } 1 \mathrm{~min} \text { at } 72^{\circ} \mathrm{C} \text { for } 30 \\
\text { cycles; final extension for } 10 \mathrm{~min} \text { at } 72^{\circ} \mathrm{C} \text {. }\end{array}$} & 1315 & \multirow{2}{*}{$\begin{array}{l}\text { Kroning } \\
\text { et al. } \\
(2016)\end{array}$} \\
\hline ica $\mathrm{D}$ & $\begin{array}{l}\text { F: AAACGTAAGAGAGGTGG } \\
\text { R: GGCAATATGATCAAGATAC }\end{array}$ & & 381 & \\
\hline
\end{tabular}

$4 \mathrm{~mL}$ of bacterial suspension was standardized with PBS buffer (0.01M, pH 7.2) to an optical density (OD) of 1.0 at $550 \mathrm{~nm}$. Subsequently, $3.6 \mathrm{~mL}$ of each bacterial suspension was added to $0.4 \mathrm{~mL}$ of xylol (Vetec).
Each mixture was vortexed for $5 \mathrm{~min}$ and then allowed to rest for $20 \mathrm{~min}$. Once the organic/aqueous phases reached equilibrium, the lower layer was removed, and the absorbance was measured at $400 \mathrm{~nm}$. 
Correia, T. M. A., Oliveira, A. P. D., Miyasato, I. F., Santos, T. M. B., Dias, F. S. (2019). Characterization of Staphylococcus aureus isolated from tilapia and utensils used in the sale of tilapia in the street markets of a semi-arid Brazilian municipality. Acta Sci. Pol. Technol. Aliment., 18(4), 413-425. http://dx.doi.org/10.17306/J.AFS.2019.0727

Table 2. Detection and indicated count interval of coagulase-positive staphylococci (CoPS) in samples of tilapia (log CFU/g) and associated utensils $\left(\log \mathrm{CFU} / \mathrm{cm}^{2}\right)$ from 5 street markets in the municipality of Petrolina

\begin{tabular}{|c|c|c|c|c|c|c|c|c|c|}
\hline \multirow{2}{*}{ Samples } & \multirow{2}{*}{$\begin{array}{l}\text { Total number } \\
\text { of samples }\end{array}$} & \multirow{2}{*}{\multicolumn{2}{|c|}{$\begin{array}{l}\text { Detection and count interval } \\
\text { number of samples }\end{array}$}} & \multicolumn{5}{|c|}{ Street markets (fairs) } & \multirow{2}{*}{ Total } \\
\hline & & & & A & $\mathrm{B}$ & $\mathrm{C}$ & $\mathrm{D}$ & $\mathrm{E}$ & \\
\hline \multirow{5}{*}{$\begin{array}{l}\text { Freshly evis- } \\
\text { cerated tilapia }\end{array}$} & \multirow{5}{*}{$\begin{array}{l}100 \\
(20 \text { per fair })\end{array}$} & no detection & & 11 & 13 & 1 & 0 & 7 & 32 \\
\hline & & detection & & 9 & 7 & 19 & 20 & 13 & 68 \\
\hline & & count interval, $\log \mathrm{CFU} / \mathrm{g}$ & $3-4.9$ & 4 & 5 & 7 & 0 & 10 & 26 \\
\hline & & & $5-6.9$ & 5 & 2 & 11 & 9 & 3 & 30 \\
\hline & & & $7-8.9$ & 0 & 0 & 1 & 11 & 0 & 12 \\
\hline \multirow{4}{*}{$\begin{array}{l}\text { Table } \\
\text { (swab) }\end{array}$} & \multirow{4}{*}{$\begin{array}{l}25 \\
(5 \text { per fair })\end{array}$} & no detection & & 3 & 2 & 2 & 3 & 3 & 13 \\
\hline & & detection & & 2 & 3 & 3 & 2 & 2 & 12 \\
\hline & & count interval, $\log \mathrm{CFU} / \mathrm{cm}^{2}$ & $3-4.9$ & 2 & 2 & 3 & 1 & 2 & 10 \\
\hline & & & $5-6.9$ & 0 & 1 & 0 & 1 & 0 & 2 \\
\hline \multirow{3}{*}{$\begin{array}{l}\text { Knife } \\
\text { (swab) }\end{array}$} & \multirow{3}{*}{$\begin{array}{l}25 \\
(5 \text { per fair })\end{array}$} & no detection & & 5 & 3 & 5 & 3 & 4 & 20 \\
\hline & & detection & & 0 & 2 & 0 & 2 & 1 & 5 \\
\hline & & count interval, $\log \mathrm{CFU} / \mathrm{cm}^{2}$ & $3-4.9$ & 0 & 2 & 0 & 2 & 1 & 5 \\
\hline
\end{tabular}

The cells highlighted in gray demonstrate the number of samples in which CoPS was detected and the number of samples with counts in the indicated intervals, $\log \mathrm{CFU} / \mathrm{g}$ or $\mathrm{CFU} / \mathrm{cm}^{2}$.

BHI without inoculum was treated as described above and used as the blank. The hydrophobicity index (HI) was determined using the following formula: $\mathrm{HI}=$ $100 \times\left(V_{i}-V_{f}\right) / V_{i}$, where $V_{i}$ is the initial absorbance and $V_{f}$ is the final absorbance. Bacteria with an $\mathrm{HI}>$ $70 \%$ were considered to be highly hydrophobic, those with an $\mathrm{HI}<30 \%$ were considered to be highly hydrophilic, and those with an $\mathrm{HI}$ of $30 \%<\mathrm{HI}<70 \%$ were considered to be moderately hydrophobic.

\section{Qualitative and quantitative determination of biofilm production}

Qualitative determination of biofilm production was performed as described by Rodrigues et al. (2017). The isolates were streaked onto plates containing Congo red agar (CRA, HiMedia), and the plates were incubated for $24 \mathrm{~h}$ at $35^{\circ} \mathrm{C}$ before being left at room temperature for another $48 \mathrm{~h}$. Colony color was used to classify each isolate in terms of biofilm production. Completely black colonies indicated isolates capable of producing biofilms; nearly black colonies indicated isolates with weaker biofilm production; and red and purple colonies indicated isolates that did not produce biofilms.

Quantification of biofilm production by isolates was performed through measurement of adhesion to microplates (Merino et al., 2009). The isolates were inoculated in TSB broth enriched with glucose and incubated at $37^{\circ} \mathrm{C}$ for $24 \mathrm{~h}$. A volume of $200 \mu \mathrm{L}$ from each culture was then added to each well and incubated at $37^{\circ} \mathrm{C}$ for $24 \mathrm{~h}$. The culture present in each microplate was discarded and three washes were performed with $200 \mu \mathrm{L}$ of autoclaved distilled water. After air drying, $100 \mu \mathrm{L}$ of $0.25 \%$ crystal violet (Laborclin) solution was added, and each microplate was incubated for $3 \mathrm{~min}$ at room temperature. Then, three more washes were performed with autoclaved distilled water. After drying, $200 \mu \mathrm{L}$ of alcohol:acetone (80:20) (Vetec) was added, and the OD was measured at 595 $\mathrm{nm}$. This test was performed in triplicate. S. aureus ATCC 25923 was used as the positive control (PC). Biofilm production was classified as follows: poor 
$(<\mathrm{PC} \mathrm{OD} / 2)$, intermediate $(\geq \mathrm{PC} \mathrm{OD} / 2$, but $<\mathrm{PC} \mathrm{OD})$ and strong biofilm formers ( $\geq$ PC OD).

\section{Detection of $S$. aureus genes related to biofilm and staphylococcal enterotoxin production}

The ability of $S$. aureus strains to produce biofilms and enterotoxins was verified according to the methodology proposed by Kroning et al. (2016) (Table 1). PCR targeting of biofilm-related genes (icaA and ica $\mathrm{D}$ ) and classic enterotoxin-related genes (sea, seb, sec, sed and see) was carried out using premixed, readyto-use GoTaq ${ }^{\circledR}$ Green Master Mix 2X (Promega), as described for the detection of the mecA and blaZ genes. S. aureus ATCC 25923 was used as a positive control for biofilm production, whereas the strains ATCC 13565 (sea and sed), ATCC 14458 (seb), ATCC 19095 (sec) and ATCC 27664 (see), provided by the FIOCRUZ, were used as positive controls for the enterotoxin genes.

\section{Statistical analysis}

For the hydrophobicity and EPS tests, statistical analysis was performed using ANOVA, and the means were compared with Scott-Knott tests $(P<0.05)$ (Sisvar ${ }^{\circledR}$, Lavras, Brazil).

\section{RESULTS AND DISCUSSION}

Detection of CoPS and identification of S. aureus

Among the samples obtained from the freshly eviscerated tilapia (muscle), table swabs and knife swabs, 68 (68\%), 12 (48\%) and 5 (20\%) CoPS-positive samples were observed, respectively (Table 2). The current legislation in Brazil for the microbiological criteria of fresh fish allows that 2 out of 5 samples may contain between 2.7 and $3.0 \log$ CFU/g CoPS (Brasil, 2001). All positive samples were in disagreement with the legal limits in force, with a CoPS count above that stipulated by the law. A greater number of positive samples were observed among the tilapia samples from street markets $\mathrm{D}$ and $\mathrm{C}$ than among those from the other markets. In addition, a greater number of positive samples were observed among the table samples from street markets $\mathrm{B}$ and $\mathrm{C}$ and among the knife samples from markets $\mathrm{B}$ and $\mathrm{D}$ than among the corresponding sample types from the other markets. Market D also stood out as having the largest enumerated population of CoPS in the tilapia samples (counts between 7 and $8.9 \log \mathrm{CFU} / \mathrm{g}$ ). In the municipality, the markets represented as A and B are older than the other ones. However, fair D serves the low-income population and is, therefore, the most popular; it is currently the largest fair in the city.

Contamination by CoPS was higher in the tables than in the knives, because the tables are made of wood - a porous surface with abrasions and crevices that can facilitate the formation of biofilms, and visibly displayed questionable levels of hygiene. In contrast, stainless steel knives were used at all the fairs. $S$. aureus strains isolated from tilapia-processing facilities located in the southeast of Brazil showed a high biofilm-forming ability on stainless steel and polystyrene (Vázquez-Sánchez et al., 2018). Coughenour et al. (2011) reported that MRSA persists for long periods on wood and stainless surfaces. Additionally, the utensils can serve as reservoirs for transmission of the pathogen to humans.

In the biochemical identification, all the typical colonies were coagulase-positive and 12 were confirmed to be $S$. aureus after positive tests for thermonuclease enzyme and amplification of the nuc gene (Table 3). The 16S rRNA gene in these 12 isolates was sequenced, and the sequences showed $99 \%$ similarity to S. aureus (NR_113956.1) in a Basic Local Alignment Search Tool (BLAST) search. Regarding the origins of these isolates, 7 corresponded to samples obtained from tilapia, 3 to those from tables and 2 to those from knives (Table 3). In general, the presence of Staphylococcus in fish is indicative of poor handling conditions during fish transport and processing or of disease in the fish (Hammad et al., 2012). In our study, the insufficient cooling and lack of hygiene both during the evisceration of the tilapia as well as in the utensils used for its sale are possible risks for the presence and growth of $S$. aureus, as the contamination of the product by pathogens can result from a combination of inadequate storage and cross-contamination by poor food-handling practices.

\section{Detection of mecA and blaz genes and phenotyping of antimicrobial resistance}

In this study, mec A and blaZ genes were detected in all 12 of the isolates (Table 3). The mecA gene, contained within the staphylococcal chromosomal cassette 
Table 3. Genotypic confirmation, origin, detection of related genes for $\beta$-lactam resistance, intercellular adhesion and enterotoxins and cell adhesion related phenotypic characteristics of $S$. aureus isolates from tilapia and associated utensils in 5 street markets in the municipality of Petrolina

\begin{tabular}{|c|c|c|c|c|c|c|c|c|c|c|c|c|c|c|c|}
\hline \multirow{3}{*}{$\begin{array}{l}\text { Isolates } \\
\text { con- } \\
\text { firmed } \\
\text { as } S . \\
\text { aureus }\end{array}$} & \multirow{3}{*}{$\begin{array}{l}\text { Street } \\
\text { market } \\
\text { (fair) }\end{array}$} & \multirow{3}{*}{$\begin{array}{l}\text { Sample } \\
\text { origin }\end{array}$} & \multicolumn{9}{|c|}{ Gene detection } & \multirow{2}{*}{\multicolumn{4}{|c|}{$\begin{array}{c}\text { Cell adhesion related phenotypic } \\
\text { characteristics }\end{array}$}} \\
\hline & & & \multicolumn{2}{|c|}{$\begin{array}{l}\beta \text {-lactam } \\
\text { resistance }\end{array}$} & \multicolumn{2}{|c|}{$\begin{array}{l}\text { intercellular } \\
\text { adhesion }\end{array}$} & \multicolumn{5}{|c|}{ enterotoxins } & & & & \\
\hline & & & $m e c \mathrm{~A}$ & blaZ & $i c a \mathrm{~A}$ & $i c a \mathrm{D}$ & sea & $s e b$ & $\mathrm{sec}$ & sed & see & $\begin{array}{l}\text { EPS } \\
\mathrm{mg}^{*}\end{array}$ & $\begin{array}{c}\text { Hydro- } \\
\text { phobicity } \\
\% * *\end{array}$ & $\begin{array}{l}\text { Quali- } \\
\text { tative } \\
\text { Biofilm }\end{array}$ & $\begin{array}{l}\text { Quan- } \\
\text { titative } \\
\text { Biofilm }\end{array}$ \\
\hline P7 & A & tilapia & + & + & - & + & - & - & - & + & - & $13.00^{\mathrm{d}}$ & $74.77^{\mathrm{f}}$ & + & moderate \\
\hline P21 & B & tilapia & + & + & - & + & - & - & - & + & - & $3.38^{\mathrm{f}}$ & $39.75^{\mathrm{i}}$ & + & weak \\
\hline P22 & B & tilapia & + & + & - & + & - & - & - & + & - & $10^{\mathrm{e}}$ & $45.06^{\mathrm{h}}$ & + & weak \\
\hline P44 & $\mathrm{C}$ & tilapia & + & + & - & + & - & - & - & + & - & $20^{\mathrm{b}}$ & $86.87^{\mathrm{c}}$ & + & strong \\
\hline P64 & $\mathrm{D}$ & tilapia & + & + & - & + & - & - & - & + & - & $20^{\mathrm{b}}$ & $88.83^{\mathrm{a}}$ & + & strong \\
\hline P79 & $\mathrm{D}$ & tilapia & + & + & - & + & - & - & - & + & - & $13.34^{\mathrm{d}}$ & $79.22^{\mathrm{e}}$ & + & moderate \\
\hline P83 & $\mathrm{E}$ & tilapia & + & + & - & + & - & - & - & + & - & $20^{\mathrm{b}}$ & $86.15^{\mathrm{d}}$ & + & strong \\
\hline SM17 & $\mathrm{D}$ & table & + & + & - & + & - & - & - & + & - & $33.41^{\mathrm{a}}$ & $88.95^{\mathrm{a}}$ & + & strong \\
\hline SM20 & D & table & + & + & - & + & - & - & - & + & - & $20^{\mathrm{b}}$ & $87.36^{\mathrm{c}}$ & + & strong \\
\hline SM24 & $\mathrm{E}$ & table & + & + & - & + & - & - & - & + & - & $10^{\mathrm{e}}$ & $46.92^{\mathrm{g}}$ & + & weak \\
\hline SF10 & B & knife & + & + & - & + & - & - & - & + & - & $16.66^{\mathrm{c}}$ & $87.82^{b}$ & + & strong \\
\hline SF23 & $\mathrm{E}$ & knife & + & + & - & + & - & - & - & + & - & $10^{\mathrm{e}}$ & $39.45^{\mathrm{i}}$ & + & weak \\
\hline
\end{tabular}

For each column, mean values with different letters are significantly different $(P<0.05)$ according to the Scott-Knott test.

$*$ Standard error $(\mathrm{SE})=0.14$.

$* * \mathrm{SE}=0.37$.

+ : positive, -: negative.

(SCCmec), encodes a variant of a penicillin-binding protein (PBP2a). This variant impairs the ability of penicillin to bind to the bacterial membrane and cause cell lysis. The blaZ gene encodes a $\beta$-lactamase that confers penicillin resistance. Resistance to penicillinase-stable penicillins is characterized as "methicillin resistance" or "oxacillin resistance". Oxacillin (or cefoxitin) results can be applied to the other penicillinasestable penicillins (cloxacillin, dicloxacillin, methicillin, and nafcillin). MRSA strains are S. aureus strains expressing mecA or utilizing another mechanism of resistance, for example, alteration in the affinity of penicillin-binding proteins for oxacillin (CLSI, 2018).

Phenotypically, 10 isolates showed resistance to 3 or more drug classes and, hence, were classified as having multidrug resistance (MDR). The highest resistance rates of the isolates (Table 4) were for oxacillin $(100 \%)$, cefoxitin $(100 \%)$ and penicillin $(91.6 \%)$. Susceptibility to $\beta$-lactams was observed in 1 isolate. Based on the results of PCR, which is considered the "gold standard" technique for detection of the mecA gene (Sakoulas et al., 2001), the sensitivity of the disc diffusion test was found to be $91.6 \%$, given that 1 of the isolates showed heteroresistance.

High rates of resistance were also observed in clindamycin $(83.3 \%)$, vancomycin $(58.3 \%)$ and erythromycin (58.3\%). A lower rate of resistance was verified for rifampicin $(8.33 \%)$. The strains were susceptible to chloramphenicol, gentamicin, ciprofloxacin, sulfamethoxazole + trimethoprim and tetracycline (Table 4). 
Correia, T. M. A., Oliveira, A. P. D., Miyasato, I. F., Santos, T. M. B., Dias, F. S. (2019). Characterization of Staphylococcus aureus isolated from tilapia and utensils used in the sale of tilapia in the street markets of a semi-arid Brazilian municipality. Acta Sci. Pol. Technol. Aliment., 18(4), 413-425. http://dx.doi.org/10.17306/J.AFS.2019.0727

Table 4. Antimicrobial resistance and resistance profiles of S. aureus strains for each antimicrobial tested, \%

\begin{tabular}{|c|c|c|c|c|c|c|c|c|c|c|c|c|c|}
\hline STRAIN & CLI & ERY & PEN & OXA & CEF & RIF & CLO & VAN & GEN & CIP & SUT & TET & $\%$ \\
\hline P7 & $\mathrm{R}$ & $\mathrm{R}$ & $\mathrm{R}$ & $\mathrm{R}$ & $\mathrm{R}$ & $\mathrm{S}$ & $\mathrm{S}$ & $\mathrm{R}$ & S & S & S & $\mathrm{S}$ & 50 \\
\hline P21 & $\mathrm{R}$ & S & $\mathrm{R}$ & $\mathrm{R}$ & $\mathrm{R}$ & S & $\mathrm{S}$ & $\mathrm{R}$ & S & S & S & S & 41.66 \\
\hline P22 & $\mathrm{R}$ & $\mathrm{S}$ & $\mathrm{R}$ & $\mathrm{R}$ & $\mathrm{R}$ & $\mathrm{S}$ & $\mathrm{S}$ & $\mathrm{R}$ & $\mathrm{S}$ & $\mathrm{S}$ & $\mathrm{S}$ & $\mathrm{S}$ & 41.66 \\
\hline P44 & $\mathrm{R}$ & $\mathrm{R}$ & $\mathrm{R}$ & $\mathrm{R}$ & $\mathrm{R}$ & I & $\mathrm{S}$ & S & $\mathrm{S}$ & $\mathrm{S}$ & $\mathrm{S}$ & $\mathrm{S}$ & 41.66 \\
\hline P64 & $\mathrm{R}$ & $\mathrm{R}$ & $\mathrm{R}$ & $\mathrm{R}$ & $\mathrm{R}$ & S & S & $\mathrm{S}$ & $\mathrm{S}$ & S & S & $\mathrm{S}$ & 41.66 \\
\hline P79 & $\mathrm{R}$ & $\mathrm{R}$ & $\mathrm{R}$ & $\mathrm{R}$ & $\mathrm{R}$ & $\mathrm{R}$ & $\mathrm{S}$ & $\mathrm{R}$ & $\mathrm{S}$ & S & $\mathrm{S}$ & S & 58.33 \\
\hline P83 & $\mathrm{S}$ & $\mathrm{S}$ & $\mathrm{R}$ & $\mathrm{R}$ & $\mathrm{R}$ & $\mathrm{S}$ & $\mathrm{S}$ & $\mathrm{S}$ & $\mathrm{S}$ & $\mathrm{S}$ & $\mathrm{S}$ & $\mathrm{S}$ & 25 \\
\hline SM17 & $\mathrm{R}$ & I & $\mathrm{R}$ & $\mathrm{R}$ & $\mathrm{R}$ & I & $\mathrm{S}$ & $\mathrm{R}$ & $\mathrm{S}$ & $\mathrm{S}$ & $\mathrm{S}$ & $\mathrm{S}$ & 41.66 \\
\hline SM20 & $\mathrm{R}$ & $\mathrm{R}$ & $\mathrm{R}$ & $\mathrm{R}$ & $\mathrm{R}$ & $\mathrm{S}$ & $\mathrm{S}$ & $\mathrm{R}$ & $\mathrm{S}$ & $\mathrm{S}$ & S & S & 50 \\
\hline SM24 & $\mathrm{R}$ & $\mathrm{R}$ & $\mathrm{R}$ & $\mathrm{R}$ & $\mathrm{R}$ & $\mathrm{S}$ & $\mathrm{S}$ & $\mathrm{R}$ & $\mathrm{S}$ & $\mathrm{S}$ & $\mathrm{S}$ & $\mathrm{S}$ & 50 \\
\hline SF 10 & I & I & S & $\mathrm{R}$ & $\mathrm{R}$ & $\mathrm{S}$ & S & $\mathrm{S}$ & S & S & S & S & 16.66 \\
\hline SF23 & $\mathrm{R}$ & $\mathrm{R}$ & $\mathrm{R}$ & $\mathrm{R}$ & $\mathrm{R}$ & I & $\mathrm{S}$ & $\mathrm{S}$ & S & $\mathrm{S}$ & S & $\mathrm{S}$ & 41.66 \\
\hline$\%$ & 83.3 & 58.3 & 91.66 & 100 & 100 & 8.33 & 0 & 58.3 & 0 & 0 & 0 & 0 & \\
\hline
\end{tabular}

$\mathrm{S}$ - susceptible, I - intermediate, R - resistant. CLI - clindamycin, ERY - erythromycin, PEN - penicillin, OXA - oxacillin, $\mathrm{CEF}$ - cefoxitin, RIF - rifampicin, CLO - chloramphenicol, VAN - vancomycin, GEN - gentamicin, CIP - ciprofloxacin, SUT sulfamethoxazole + trimethoprim, TET - tetracycline.

Light gray highlighting - moderately susceptible (intermediate).

Dark gray highlighting - resistant.

The high resistance rates of the isolates to these antimicrobials in this study are noteworthy, as these are the drugs used as standard therapies against $S$. aureus infections. Additionally, according to the CLSI (2018), other $\beta$-lactam agents (penicillin/ $\beta$-lactam inhibitor combinations), carbapenems, and cephems (with the exception of MRSA-active cephalosporins) can be active in vitro against oxacillin-resistant $S$. aureus; however, these agents are not clinically effective.

MRSA strains have a high potential for pathogenicity and MDR. Therefore, MRSA is of great concern to human health. These strains have multiple mechanisms of resistance to new antibiotics. They also have a complex epidemiology and low host specificity; MRSA can be easily transferred between various animal species and humans. This transfer among species culminates in humans serving as potential reservoirs for new virulent isolates (Doulgeraki et al., 2017; Hammad et al., 2012). The emergence of MRSA negatively affects the trade of animal products for consumption.
Healthy aquaculture fish are reservoirs of MRSA (Fri et al., 2018). In this study, the points of sale for tilapia presented conditions encouraging the proliferation of MRSA, such as a lack of temperature control during the handling, packaging and sale of the fish, as specified by Othman et al. (2018). Additional factors include direct contact of the tilapia with the hands of those involved in processing and an absence of proper hygiene for the utensils used in the sales outlets. This lack of hygiene during handling is responsible for the spread of MRSA to humans (Hammad et al., 2012).

\section{Phenotypic features and detection of biofilm-related genes}

There was a significant difference $(P<0.05)$ in EPS production among the different $S$. aureus strains. The 12 isolates showed EPS production levels ranging from 3.38 to $33.41 \mathrm{mg}$ (Table 3). The SM17 isolate, which originated from a table swab, presented higher EPS production than the other isolates. According to 
Schiavão-Souza et al. (2007), EPS production levels can vary between 10 and $1000 \mathrm{mg} / \mathrm{L}$, and production below $10 \mathrm{mg} / \mathrm{L}$ is considered to be very low. All isolates showed a low level of EPS production. However, it is important to note that EPS production may vary as a consequence of substrate availability, temperature and aeration. Therefore, in vitro quantification may differ from in vivo quantification, since external conditions have a significant effect on the production and composition of EPS (Joyce et al., 2003; Vázquez-Sánchez and Rodríguez-López, 2018).

The major EPS produced by Staphylococcus is PIA, whose production is mediated by the icaADBC locus. This EPS is responsible for cell aggregation. There is a clear relationship between EPS production and biofilm formation, and one of the most important functions of EPS is the protection of the biofilm-producing microorganisms against adverse environmental conditions. EPS also decreases drug permeability, contributing to drug tolerance and the emergence of colonies with MDR (Joyce et al., 2003).

Regarding hydrophobicity, 8 isolates showed high hydrophobicity and 4 medium hydrophobicity (Table 3). The isolate SM17 also presented high hydrophobicity $(P<0.05)$ and originated from a table swab from fair $\mathrm{D}$, where there were $S$. aureus-positive samples with high counts (Table 2). One of the interaction forces responsible for adhesion is hydrophobicity. Microbial strains with higher hydrophobicity present a greater ability to adhere to surfaces and to form biofilms (Vázquez-Sánchez and Rodríguez-López, 2018).

In the qualitative evaluation of biofilm production, all of the isolates presented positive results (Table 3 ). Qualitatively, 6 isolates were classified as strong, 2 as moderate and 4 as weak biofilm producers. Upon genotyping, the icaD gene was detected in all isolates, but the icaA gene was not. The absence of the icaA gene in $i c a \mathrm{D}$-positive strains has already been reported in other studies (Basanisi et al., 2017; Carvalho et al., 2019; Ciftci et al., 2009; Suvajdžić et al., 2017). Ciftci et al. (2009) and Suvajdžić et al. (2017) suggested the possibility of mutation in the icaA gene. It is noteworthy that the presence of a protein resulting from the translation of the $i c a \mathrm{D}$ gene is required for the activity of icaA. The icaA gene undergoes translation and results in a protein which has a structure homologous to $\mathrm{N}$-acetyl Glucosaminyltransferase. IcaD has been reported to play a critical role in the expression of N-acetyl Glucosaminyltransferase (Gupta et al., 2017). In addition, complex mechanisms that are independent of the absence or presence of the ica gene are involved in the production of biofilms by $S$. aureus. Despite the strong relationship between the ica gene and biofilm formation in $S$. aureus, strains that contain ica will not necessarily form biofilms (Vázquez-Sánchez and Rodríguez-López, 2018). Kroning et al. (2016) observed no relationship between the degree of biofilm formation and the presence of ica genes.

In our study, 6 isolates that were classified as strong biofilm producers also showed a high cell surface hydrophobicity and the presence of the icaD gene. Table and knife swabs, as well as fish samples, contained biofilm-producing isolates, particularly the swabs from the wooden tables. In addition to enhancing the survival of staphylococci, biofilms increase the pathogenicity of these bacteria, as they allow for the exchange of virulence factors, such as multiple antimicrobial resistance. Beyond the other described ways in which EPS hinders antimicrobial function, it can also act through direct cell-to-cell contact to facilitate the transfer of plasmids which confer drug resistance (Doulgeraki et al., 2017).

\section{Detection of staphylococcal enterotoxin genes}

The gene for enterotoxin $\mathrm{D}$ was detected in all isolates (Table 3). As part of this study, the antimicrobial resistance, biofilm-producing ability, and capability of the isolates to produce enterotoxins were characterized.

High concentrations of se-carrying S. aureus were found in several control points of tilapia-processing facilities (Vázquez-Sánchez et al., 2018). According to Burgos et al. (2018), during commercial tilapia production, water, environmental factors and handling provide favorable conditions for the growth of enterotoxigenic pathogens. Generally, the contamination of fish with enterotoxigenic $S$. aureus is due to improper handling, and this contamination can lead to food poisoning in consumers.

Among the enterotoxins produced, the classic staphylococcal enterotoxins (A, B, C, D, and E) are responsible for $95 \%$ of staphylococcal food poisoning (Kroning et al., 2016). Additionally, enterotoxin D is the most common serotype in $S$. aureus strains associated with food poisoning (Sihto et al., 2016). Small 
amounts of enterotoxins (approximately $1 \mu \mathrm{g}$ of toxin per $100 \mathrm{~g}$ of food) are sufficient to produce clinical manifestations. The symptomatology is dependent on the quantity ingested and the susceptibility of the individual. The commonly described symptoms are nausea, vomiting (in spurts), abdominal pain, dizziness, diarrhea, shivering and general weakness, sometimes associated with a moderate fever. In the majority of cases, recovery occurs within $24-48 \mathrm{~h}$ without specific treatment (Hennekinne et al., 2012). Although this food poisoning is often short-lived and causes mild symptoms, many cases are neglected, and the actual number of affected patients has not been recorded (Chaves et al., 2018).

The gene encoding enterotoxin $\mathrm{D}$ can be carried by plasmids (Sihto et al., 2016). As previously reported, the structure of the biofilm enhances the pathogenicity of $S$. aureus strains, as it enables the sed gene to be easily transferred between cells. Contamination of fish by enterotoxigenic $S$. aureus can be avoided through the adoption of good hygiene practices by those involved in the handling and commercial production of tilapia.

\section{CONCLUSION}

This study identified MRSA isolates with virulence properties in all street markets in Petrolina, Brazil. Thus, MRSA is in circulation, and tilapia may be a vehicle for staphylococcal food poisoning and the dissemination of MDR strains to consumers. Additionally, these MRSA strains have become constitutive microbiota, as they were present and persistent (as demonstrated by their ability to produce biofilms) on the utensils used for the commercial distribution of tilapia.

The detection of MRSA in tilapia and on utensils used in the sale of tilapia in fairs necessitates the issuance of an alert to the consumers of this product. This survey was conceived in conjunction with the Municipal Sanitary Surveillance Agency, and educational measures for the prevention of foodborne diseases have been proposed that involve education and training for handlers in sanitary practices. Additionally, improvements in the organization of markets in the municipality have been proposed with the aim of offering better-quality and safer animal products to the population.

\section{ACKNOWLEDGEMENTS}

We offer our sincere thanks to the entire staff of the Municipal Sanitary Surveillance Agency of Petrolina; in particular, the coordinator, Jarbas Costa de Oliveira. Thank you very much for your excellent partnership. We are also grateful to the Coordination for the Improvement of Higher Education Personnel (CAPES) for a scholarship and to Fundação Oswaldo Cruz (FIOCRUZ) for providing the $S$. aureus strains used as positive controls in this study.

\section{REFERENCES}

Bahia Pesca (2014). Bahia Pesca and Codevasf join forces to strengthen fish farming in the state. Retrieved January 30, 2019, from: http://www.bahiapesca.ba.gov. br/2014/09/255/Bahia-Pesca-e-Codevasf-se-unem-para-fortalecer-a-piscicultura-no-estado.html

Basanisi, M. G., La Bella, G., Nobili, G., Franconieri, I., La Salandra, G. (2017). Genotyping of methicillin-resistant Staphylococcus aureus (MRSA) isolated from milk and dairy products in South Italy. Food Microbiol., 62, 141146. https://doi.org/10.1016/j.fm.2016.10.020

Brasil (2001). Ministry of Health. RDC Resolution no 12, January 2, 2001. Technical regulations on food microbiological standards. Offic. J. Federal Gov. Brazil, 1. Retrieved November 17, 2019, from: http://portal.anvisa.gov.br/documents/33880/2568070/RDC_12_2001. pdf/15ffddf6-3767-4527-bfac-740a0400829b

Brasil (2003). Ministry of Agriculture, Livestock and Supply. Normative Instruction $n^{\circ} 62$, August 26, 2003. Official analytical methods for the control of products of animal origin and water. Offic. J. Federal Gov. Brazil, 1. Retrieved January 30, 2019, from: http://extranet.agricultura.gov.br/sislegis-consulta/consultarLegislacao. do?operacao $=$ visualizar\&id $=2851$

Burgos, M. J. G., Romero, J. L., Pulido, R. P., Gálvez, R. L. A. (2018). Analysis of potential risks from the bacterial communities associated with air-contact surfaces from tilapia (Oreochromis niloticus) fish farming. Environ. Res., 160, 385-390. https://doi.org/10.1016/j.envres.2017.10.021

Carvalho, S. P., Almeida, J. B., Andrade, Y. M. F. S., Silva, L. S. C., Chamon, R. C. C., Santos, K. R. N., Marques, L. M. (2019). Molecular characteristics of methicillinresistant Staphylococcus aureus isolates from hospital and community environments in northeastern Brazil. Braz. 
Correia, T. M. A., Oliveira, A. P. D., Miyasato, I. F., Santos, T. M. B., Dias, F. S. (2019). Characterization of Staphylococcus aureus isolated from tilapia and utensils used in the sale of tilapia in the street markets of a semi-arid Brazilian municipality. Acta Sci. Pol. Technol. Aliment., 18(4), 413-425. http://dx.doi.org/10.17306/J.AFS.2019.0727

J. Infect. Dis., 23, 2, 134-138. https://doi.org/10.1016/j. bjid.2019.04.005

CDC-NORS - Centers for Disease Control and Prevention - National Outbreak Reporting System (2019). NORS Dashboard. Retrieved November 26, 2019, from: https://wwwn.cdc.gov/norsdashboard/

Chaves, D. R., Pradella, F., Turatti, M. A., Amaro, E. C., da Silva, A. R., Farias, A. S., ..., Khaneghah, A. M. (2018). Evaluation of Staphylococcus spp. in food and kitchen premises of Campinas, Brazil. Food Contr., 84, 463470. https://doi.org/10.1016/j.foodcont.2017.09.001

Ciftci, A., Findink, A., Onuk, E. E., Savasan, S. (2009). Detection of methicillin resistance and slime factor production of Staphylococcus aureus in bovine mastitis. Braz. J. Microbiol., 40, 2, 254-261. http://dx.doi.org/10.1590/ S1517-83822009000200009

CLSI - Clinical and Laboratory Standards Institute (2018). Performance standards for antimicrobial susceptibility testing. CLSI supplement M100 (28 $8^{\text {th }}$ ed.).

Coughenour, C., Stevens, V., Stetzenbach, L. D. (2011). An evaluation of methicillin-resistant Staphylococcus aureus survival on five environmental surfaces. Microb. Drug Resist., 17, 3, 457-461. https://doi.org/10.1089/ mdr.2011.0007

Doulgeraki, A. I., Di Ciccio, P., Ianieri, A., Nychas, G. J. E. (2017). Methicillin-resistant food-related Staphylococcus aureus: a review of current knowledge and biofilm formation for future studies and applications. Res. Microbiol., 168, 1, 1-15. https://doi.org/10.1016/j. resmic.2016.08.001

EFSA - European Food Safety Authority (2016). The European Union summary report on trends and sources of zoonoses, zoonotic agents and food-borne outbreaks in 2015. EFSA J., 14, 12, 1-231. https://doi.org/10.2903/j. efsa.2016.4634

Fri, J., Ndip, R. N., Njom, H. A., Clarke, A. M. (2018). First report of methicillin-resistant Staphylococcus aureus in tank cultured dusky kob (Argyrosomus japonicus), and evaluation of three phenotypic methods in the detection of MRSA. J. Food Safety, 38. https://doi.org/10.1111/ jfs. 12411

Gatti Junior, P., Assunção, A. W. A., Baldin, J. C., Amaral, L. A. (2014). Microbiological quality of whole and filleted shelf-tilapia. Aquacult., 433. https://doi.org/10.1016/j. aquaculture.2014.06.015

Gupta, A., Mishra, S., Singh, S., Mishra, S. (2017). Prevention of IcaA regulated poly $\mathrm{N}$-acetyl glucosamine formation in Staphylococcus aureus biofilm through new-drug like inhibitors: In silico approach and MD simulation study. Microb. Pathog., 110. https://doi.org/10.1016/j. micpath.2017.05.025

Hammad, A. M., Watanabe, W., Fujii, T., Shimamoto, T. (2012). Occurrence and characteristics of methicillin-resistant and -susceptible Staphylococcus aureus and methicillin-resistant coagulase-negative staphylococci from Japanese retail ready-to-eat raw fish. Int. J. Food Microbiol., 156, 3, 286-289. https://doi.org/10.1016/j. ijfoodmicro.2012.03.022

Hennekinne, J. A., Buyser, M. L., Dragacci, S. (2012). Staphylococcus aureus and its food poisoning toxins: characterization and outbreak investigation. FEMS Microbiol. Rev., 36, 4, 815-836. https://doi.org/10.1111/ j.1574-6976.2011.00311.x

IBGE - Instituto Brasileiro de Geografia e Estatística (2010). Cartographic bases - digital meshes: municipal and census tract. Retrieved January 21, 2019, from: http://mapas.ibge.gov.br/bases-e-referenciais/bases-cartograficas/malhas digitais.html

Kroning, I. S., Iglesias, M. A., Sehn, C. P., Gandra, T. K. V., Mata, M. M., da Silva, W. P. (2016). Staphylococcus aureus isolated from handmade sweets: biofilm formation, enterotoxigenicity and antimicrobial resistance. Food Microbiol., 58, 105-111. https://doi.org/10.1016/j. fm.2016.04.001

Joyce, J., Abeygunawardana, C., Xu, Q., Cook, J., Heple, R., Przysiecki, C., ..., Jansen, G. E. M. (2003). Isolation, structure characterization, and immunological evaluation of a high-molecular-weight exopolysaccharide from Staphylococcus aureus. Carbohydr. Res., 338, 9, 903922. https://doi.org/10.1016/S0008-6215(03)00045-4

Lange, C. C., Brito, M. A. V. P., Brito, J. R. F., Arcuri, E. F., Souza, G. N., Marchado, M. A., ..., Salimena, A. P. S. (2011). Uso de PCR e sequenciamento do rDNA 16S para identificação de bactérias do gênero Staphylococcus isoladas de mastite bovina. Pesq. Vet. Bras., 31, 1, 36-40. http://dx.doi.org/10.1590/S0100-736X2011000100006

Martinon, A., Cronin, U. P., Quealy, J., Stapleton, A., Wilkinson, M. G. (2012). Swab sample preparation and viable real-time PCR methodologies for the recovery of Escherichia coli, Staphylococcus aureus or Listeria monocytogenes from artificially contaminated food processing surfaces. Food Contr., 24, 1-2, 86-94. https:// doi.org/10.1016/j.foodcont.2011.09.007

Merino, N., Toledo-Arana, A., Vergara-Irigaray, M., Valle, J., Solano, C., Calvo, E., ..., Lasa, I. (2009). Protein Amediated multicellular behavior in Staphylococcus aureus. J. Bacteriol., 191, 1, 1-6. https://doi.org/10.1128/ JB.01222-08 
Correia, T. M. A., Oliveira, A. P. D., Miyasato, I. F., Santos, T. M. B., Dias, F. S. (2019). Characterization of Staphylococcus aureus isolated from tilapia and utensils used in the sale of tilapia in the street markets of a semi-arid Brazilian municipality. Acta Sci. Pol. Technol. Aliment., 18(4), 413-425. http://dx.doi.org/10.17306/J.AFS.2019.0727

Ossa, R. P. L., Prado, S. I., Cervi, M. C., Lima, D. A. F. S., Martinez, R., Rodrigues, F. B. (2018). Is communityassociated methicillin-resistant Staphylococcus aureus (CA-MRSA) an emerging pathogen among children in Brazil? Braz. J. Infect. Dis., 22, 5, 371-376. https://doi. org/10.1016/j.bjid.2018.10.276

Othman, B. R., Kuan, C. H., Mohammed, A. S., Cheah, Y. K., Tan, C. W., New, C. Y., ..., Radu, S. (2018). Occurrence of methicillin-resistant Staphylococcus aureus in raw shellfish at retail markets in Malaysia and antibacterial efficacies of black seed (Nigella sativa) oil against MRSA. Food Contr., 90, 324-331. https://doi. org/10.1016/j.foodcont.2018.02.045

Rodrigues, L. B., Santos, L. R., Rizzo, N. N., Tagliari, V. Z., Oliveira, A. P. D., Trenhago, G., ..., Nascimento, V. P. (2009). Avaliação da hidrofobicidade e da formação de biofilme em poliestireno por Salmonella Heidelberg isoladas de abatedouro avícola. Acta Sci. Vet., 37, 3, 225-230. https://doi.org/10.22456/1679-9216.16333

Rodrigues, J. B. S., Carvalho, R. J., Souza, N. T., Sousa Oliveira, K., Franco, O. L., Schaffner, D, ..., Magnani, M. (2017). Effects of oregano essential oil and carvacrol on biofilms of Staphylococcus aureus from food-contact surfaces. Food Contr., 73, Part B, 1237-1246. https:// doi.org/10.1016/j.foodcont.2016.10.043

Sakoulas, G., Gold, H. S., Venkataraman, L., Degirolami, P. C., Eliopoulos, G. M., Qian, Q. (2001). Methicillin-Resistant Staphylococcus aureus: comparison of susceptibility testing methods and analysis of mecA-positive susceptible strains. J. Clin. Microbiol., 39, 11, 3946-3951. https://doi.org/10.1128/JCM.39.11.39463951.2001

Sawant, A. A., Gillespie, B. E, Oliver, S. P. (2009). Antimicrobial susceptibility of coagulase-negative Staphylococcus species isolated from bovine milk. Vet. Microbiol., 134, 1-2, 73-81. https://doi.org/10.1016/j. vetmic.2008.09.006
Schiavão-Souza, T. D., Yuhara, T. T., Castro-Gómez, R. J. H., Garcia, S. (2007). Production of exopolysaccharides by probiotic bacteria: optimisation of the culture medium. Braz. J. Food Technol., 10, 1, 27-34. http://bjft.ital. sp.gov.br/arquivos/artigos/v10n1269a.pdf

Sihto, H. M., Susilo, Y. B., Tasara, T., Radstrom, P. (2016). Effect of sodium nitrite and regulatory mutations $\Delta a g r$, $\Delta s a r \mathrm{~A}$, and $\triangle \operatorname{sig} \mathrm{B}$ on the mRNA and protein levels of staphylococcal enterotoxin D. Food Contr., 65, 37-45. https://doi.org/10.1016/j.foodcont.2016.01.007

Suvajdžić, B., Teodorović, V., Vasilev, D., Karabasil, N., Dimitrijević, M., Dordević, J., Katić, V. (2017). Detection of icaA and icaD genes of Staphylococcus aureus isolated in cases of bovine mastitis in the Republic of Serbia. Acta Vet. (Beograd), 67, 2, 168-177. https://doi. org/10.1515/acve-2017-0015

Van Geel-Schutten, G. H., Flesch, F., Brink, T., Smith, M. R., Dijkhuizen, L. (1998). Screening and characterization of Lactobacillus strains producing large amounts of exopolysaccharides. Appl. Microbiol. Biotechnol., 50, 697-703. https://doi.org/10.1007/s002530051353

Vázquez-Sánchez, D., Rodríguez-López, P. (2018). Staphylococcus aureus. In A. Fetsch (Ed.), Chapter 5 - Biofilm formation of Staphylococcus aureus (pp. 87-103). Amsterdam: Elsevier Acad. Press. https://doi.org/10.1016/ B978-0-12-809671-0.00005-X

Vázquez-Sánchez, D., Galvão, J. A., Oetterer, M. (2018). Contamination sources, biofilm-forming ability and biocide resistance of Staphylococcus aureus in tilapiaprocessing facilities. Food Sci. Technol. Int., 24 , 3, 209-222. https://doi.org/10.1177/1082013217742753

Xing, X., Zhang, Y., Wu, Q., Wang, X., Ge, W., Wu, C. (2016). Prevalence and characterization of Staphylococcus aureus isolated from goat milk powder processing plants. Food Contr., 59, 644-650. https://doi. org/10.1016/j.foodcont.2015.06.042 